\title{
Cultural representation and intercultural interaction in textbooks of English as an international language
}

\author{
Tomy Kartika Putra ${ }^{1}$, Dewi Rochsantiningsih ${ }^{2}$, Slamet Supriyadi ${ }^{3}$ \\ 1,2 Department of English Education, Faculty of Teacher Training and Education, Universitas \\ Sebelas Maret, Surakarta, Indonesia \\ ${ }^{3}$ Department of Fine Arts Education, Faculty of Teacher Training and Education, Universitas \\ Sebelas Maret, Surakarta, Indonesia \\ ${ }^{1}$ tomkartika@student.uns.ac.id (corresponding author) \\ 2 dewi_roch@hotmail.com \\ ${ }^{3}$ pripus.lppmuns@yahoo.com
}

\begin{abstract}
The present study attempts to scrutinize the manifestation of cultures and intercultural interactions in English textbooks. It investigates three English textbooks for twelfth-grade students produced by three relatively major publishers in Indonesia by employing cultural content and intercultural interaction analysis. The findings show that the examined textbooks do not appropriately demonstrate cultural diversity in the international context as cultures of Indonesia and English-speaking countries have their dominancy. Also, the textbooks mostly demonstrate intercultural interactions in fragmented, limited, and superficial ways. Some recommendations are addressed for future textbooks authors and publishers as well as English teachers. The results suggest textbook publishers and authors include more the material about international culture and to provide more the demonstration of deep intercultural interaction. Moreover, teachers need to be creative by adding supplementary cultural materials to patch up the shortcomings of the textbooks.
\end{abstract}

Keywords: cultural content; cultural representation; English textbook; English as an international language; intercultural interaction 
How to cite this paper (in APA style): Putra, T. K., Rochsantiningsih, D., \& Supriyadi, S. (2020). Cultural representation and intercultural interaction in textbooks of English as an international language. Journal on English as a Foreign Language, 10(1), 163-184. https://doi.org/10.23971/jefl.v10i1.1766

DOI: https://doi.org/10.23971/jefl.v10i1.1766

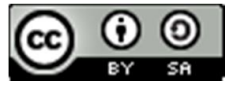

It is widely recognized that English as a foreign language (EFL) education should not only lead students to become communicative but also gain sufficient cultural knowledge and awareness (Baker, 2012a; Baker, 2012b; Byram, 1997). Cultural knowledge and awareness are believed as important things to avoid a humorous incident or even serious miscommunication and misunderstanding (Chlopek, 2008). Therefore, it is argued that culture in English teaching and learning is crucial and seen as essential elements of any language teaching materials (Tajeddin \& Teimournezhad, 2015). Since English earns its status as a lingua franca (Ishikawa, 2016; Jenkins, 2012) in which English communication takes place between people from different cultural backgrounds, the hegemony of native-speakers' norms in English language teaching is challenged (Shin et al., 2011). In other words, English teaching and learning are encouraged not only to cover cultures of English-speaking countries but also to intercultural perspectives (Baker, 2012a; Baker, 2012b; Bennett et al., 2003; Byram, 1997).

A similar spirit has appeared in Indonesia. Since the Indonesian Ministry of Education (MOE) established a new curriculum in 2013, the sociological background and ability started to gain momentum (Widodo, 2016). The curriculum is designed to make sure Indonesians graduates ready to be international citizens who have faith, as well as being prolific, inventive, and passionate so that they can contribute not only to their fellow national citizens, but also international civilization (Widodo, 2016). Further, Indonesians are projected to become individuals who are tolerant of other people that have different religions, social as well as cultural values, and willing to work hard; and creative (Setyono \& Widodo, 2019). In the relation of English language teaching, the current curriculum views English as a globally-used language and subsequently has a responsibility to embrace not only linguistics-based knowledge (four language skills and grammar) but also the knowledge of cultural diversity whether in the level of national and international. By doing so, students are expected to achieve the ability to communicate in intercultural conditions effectively.

Journal on English as a Foreign Language, 10(1), 163-184

Copyright @ 2020 by JEFL, p-ISSN 2088-1657; e-ISSN 2502-6615 
Due to the shifting role of English language teaching (ELT) from EFL into English as a lingua franca (ELF) and the raising awareness of the importance of culture, it is unsurprising that there have been a large number of investigations discussing the position of English in various cultural conditions in language textbook (Kusumaningputri \& Widodo, 2018; Setyono \& Widodo, 2019; Shin et al., 2011; Song, 2013; Tajeddin \& Teimournezhad, 2015; Weninger \& Kiss, 2013; Yuen, 2011). Despite its potential limitations such as containing inauthentic language, distorting content, or deskilling teachers (Richards, 2001), language textbooks are still undoubtedly crucial in the process of both teaching and learning (Ndura, 2004; Song, 2013). It is believed that language materials, especially textbooks, in which they implicitly and explicitly transmit societal values, assumptions, and images, meaningfully affect students' development of knowledge and their views of themselves and other persons (Ndura, 2004).

However, all textbooks depict cultural content in different ways. Textbook developers and policymakers may have their agenda in deciding to which cultural elements to be shaped (Chapelle, 2009; Rashidi et al., 2016; Tajeddin \& Teimournezhad, 2015). They tend to include or exclude detailed cultural elements based on the context, aims, and needs of the learners. Biased textbooks may, in turn, lead to a subjective worldview (Song, 2013). Rather than appreciating cultural differences, students may discriminate and prefer certain cultures over others instead. An English textbook should be inclusive so that effective teaching and learning can be created (Ndura, 2004). Ndura (2004) stated that an inclusive textbook is instrumental to raise students' cultural awareness in which it embraces both cultural diversity and life experiences that students encounter in daily life. Therefore, the balanced cultural content in textbooks is instrumental to make students avoid a subjective judgment over others and to develop theirs.

Language and culture are undoubtedly closely related (Baker, 2012a; Baker, 2012b; Liddicoat \& Scarino, 2013). Putting it in another way, learning language is not only learning an expression or its meaning but also a component of culture depicted in the language. Culture takes a crucial role in language as Bennett et al. (2003) state "the person who learns a language without learning culture risks becoming a fluent fool." Indeed, culture has long been discussed in the understanding of communicative competence proposed by Hymes (1972) with his emphasis on the sociolinguistic ability. However, due to the phenomena of English as a lingua franca, many believe that communicative competence underlying Communicative Language Teaching (CLT) needs to be refined to address sufficient recognition of the intercultural

Journal on English as a Foreign Language, 10(1), 163-184

Copyright (C) 2020 by JEFL, p-ISSN 2088-1657; e-ISSN 2502-6615 
elements (Baker, 2012a; Tajeddin \& Teimournezhad, 2015). It might happen due to the fact that communicative competence only deals with certain social norms for the appropriateness of language use and does not adequately provide an understanding of intercultural conditions.

As early mentioned, English is no longer exclusively seen as a language of the Anglosphere (e.g. Britain and the USA). English is increasingly used by non-native speakers as an international language. Nevertheless, studies investigating culture in English textbooks show the domination of certain cultural groups over others (Rashidi et al., 2016; Shin et al., 2011; Song, 2013; Tajeddin \& Teimournezhad, 2015; Taylor-Mendes, 2009; Yuen, 2011). Yuen (2011) investigated two textbook series used in Hong Kong regarding the representation of foreign cultures. By analyzing the texts and images relating to foreign cultures, the author finds that the examined materials favor the cultures of English-speaking countries and have a tendency to exclude the cultures of Africa. Shin et al., (2011) utilize Kachru's (1985) model of inner (English is used as a first language), outer (English is used as a second language), and expanding (English is learned as a second language) countries to scrutinize the representation of cultures in 25 textbooks used in several Asia countries. The findings show that, although the textbooks are designed for international learners, the findings report the redundancy of cultures from inner-circle countries. They argue the findings indicate the inner cultures are more appreciated than those in the outer as well as expanding circle.

Other studies approached culture in textbooks with the terms of "hidden agenda" (Rashidi et al., 2016; Tajeddin \& Teimournezhad, 2015). Rashidi et al. (2016) investigated cultural contents in English textbooks that are made and taught in inner, outer, and expanding circle countries. The investigation involves three textbook series including two volumes in which the textbooks are designed to be used by students with an age range of 11-15. The results show there are differences among the examined textbooks of all three circles. Textbooks that are made in the inner-circle countries favor L1 and L2 cultures. Meanwhile, textbooks that are made in the expanding circle countries contain more L1 and international cultural contents. Moreover, textbooks of the outercircle countries tend to contain L1, L2, and international cultural contents. Tajeddin and Teimournezhad (2015) concluded that the most cultural elements manifested in localized textbooks in Iran are culturally neutral. Meaning, the textbooks show the tendency to cover cultural elements that do not refer to any particular cultures. In other words, the examined textbooks seem to avoid any references to the target cultures or other cultures.

Journal on English as a Foreign Language, 10(1), 163-184

Copyright @ 2020 by JEFL, p-ISSN 2088-1657; e-ISSN 2502-6615 
Cultural content analysis in English textbooks is also under "cultural bias" terms which are usually based on gender, race, nationality, and so on (Otlowski, 2003; Sherman, 2010; Song, 2013; Taylor-Mendes, 2009). Otlowski's (2003) analysis was aimed at examining the depiction of women in stereotypical roles and the representation of ethnic groups. He finds that a language textbook used throughout Japan depicted women in roles that no longer accurately represent their role in society where the textbook frequently demonstrates a stereotyped portrayal of women as homemakers and mothers. Besides, the findings indicate that the textbook is lack of cultural content related to the minorities. Song (2013) analyzed four English textbooks developed based on the Korean national curriculum. She concludes that the characters in the textbook are dominated by white and male. Also, the textbooks are believed to favor American cultures. Sherman (2010) revealed that the representation of the nonnative speakers of English in Korean textbooks is not depicted in a fair and unbiased way. The author reveals that the textbook often illustrates native speakers of English to have more positive and respected roles than non-natives. Moreover, Taylor-Mendes (2009) investigated the perception held by students and teachers in Brazil of English textbooks. Her findings capture racial stereotypes where white persons/characters are positioned in a powerful, prominent, and superior role. On the other hand, African-American characters are positioned in powerless, unimportant and inferior.

In the Indonesian context, studies focusing on cultural elements in English textbooks are growing in numbers (Hermawan \& Lia, 2012; Munandar \& Ulwiyah, 2012; Parlindungan et al., 2018; Setyono \& Widodo, 2019). Setyono \& Widodo (2019) analyzed multicultural values in an English textbook for Indonesian secondary school students and how the values might affect the students' intercultural competence. The findings reveal four values contained in the investigated textbook, namely respecting for diversity (pluralism), respecting for the indigenous people's rights, experiencing peace with nature, and increasing in value of cultural products. Despite having a sufficient amount of multicultural topics, the textbook still underrepresented cultural materials from Asian and African countries. Hermawan and Lia (2012) investigated cultural contents in English textbooks for elementary school students. The objectives are to know whose culture (Indonesian or non-Indonesian) is most frequently presented, and how the culture is presented (sense of aesthetic, sociological, semantic, and pragmatic or sociolinguistics). The findings reveal that the investigated textbooks favor Indonesian culture, and predominantly cover sociological sense. The tendency to favor Indonesian cultures can also be found in textbooks used in senior high schools (Munandar \& Ulwiyah, 2012).

Journal on English as a Foreign Language, 10(1), 163-184

Copyright (C) 2020 by JEFL, p-ISSN 2088-1657; e-ISSN 2502-6615 
Parlindungan et al. (2018) made an attempt to report the representation of Indonesian cultures in two English textbooks for junior high school students. By employing a semiotic approach, the authors find the imbalanced and unequal representation of Indonesian culture in that the textbooks do not sufficiently include culture from minority groups.

What can be drawn from the previous studies above is that an English textbook has a strong tendency to favor certain cultures, ethnicities, or, gender. However, if English as lingua franca should be taken into account, textbooks should expose learners to not only cultures of the Anglosphere, but also international countries (Shin et al., 2011; Yuen, 2011). Besides, it is also important to emphasize learner's own culture to help them express their cultural identity (Tajeddin \& Teimournezhad, 2015). The thing is that intercultural teaching is more than simple cultural facts (Shin et al., 2011). English textbooks are also supposed to improve students' communication skills and raise intercultural competence (e.g. awareness) (Shin et al., 2011; Song, 2013). However, in the Indonesian context, studies focusing not only on cultural facts but also on intercultural communication remain limited. The above discussion inspires the present study to undertake a deep examination of cultural representation and intercultural interaction in English textbooks in Indonesia.

The next sector of this paper deals with the place of culture as well as intercultural competence in language teaching. Later on, it delivers how the present research has been developed by discussing textbook corpus and framework of analysis. Next, it displays the findings of the cultural and intercultural communication identified in the examined textbooks. At last, it discusses the findings of the present study in light of that of the previous investigations and gives some recommendations for future textbooks authors and publishers, as well as English teachers.

\section{METHOD}

\section{Textbook Corpus}

This study analyzes three English textbooks designed for Indonesian learners in grade 12. All the textbooks are published by different Indonesian publishers. In Indonesia, there are two kinds of textbooks which are compulsory textbooks and supplementary ones-both of them are based on the current curriculum. Compulsory textbooks are textbooks that are published by the government. Meanwhile, supplementary or optional textbooks are 
published by private publishers. Out of four examined textbooks, one belongs to the compulsory textbook entitled Bahasa Inggris (Widiati et al., 2018). The other two are Pathway to English (Sudarwati \& Grace, 2018) and Contextual English (Sugeng et al., 2019) that are published by Erlangga and Tiga Serangkai respectively. All the textbooks have a different number of units (see Table 1). They are authored by local experts and commonly used in Indonesia, a country that has more than two million 12 grade students.

Table 1. The examined textbooks

\begin{tabular}{lcccc}
\hline \multicolumn{1}{c}{ Title } & Author & Publisher & $\begin{array}{c}\text { Number of } \\
\text { unit }\end{array}$ & Year \\
\hline Bahasa Inggris & $\begin{array}{c}\text { Utami Widiati } \\
\text { Zuliati Rohmah } \\
\text { Furaida }\end{array}$ & Government & 11 & 2018 \\
$\begin{array}{l}\text { Pathway to } \\
\begin{array}{l}\text { English } \\
\text { Contextual } \\
\text { English }\end{array}\end{array}$ & $\begin{array}{c}\text { Eudia Grace } \\
\text { Bambang Sugeng } \\
\text { Fatyana R. Saputri } \\
\text { Anindyka S. Trisnasih }\end{array}$ & Erlangga & 8 & 2018 \\
& Tiga & 7 & 2019 \\
\hline
\end{tabular}

\section{The Framework of Data Analysis}

\section{Cultural representation}

The cultural representation in the textbook was analyzed based on the approach suggested by Yuen (2011). The main consideration of determining the approach is that the researcher demonstrated it clearly and comprehensively. Yuen (2011) analyzed foreign cultures in English textbooks used by Hong Kong students by using a framework consisting of four aspects of culture - products, practices, perspectives, and persons. Products can be recognized as the products of a civilization that mainly deal with artifacts or a system of code, such as food, print, travel or place, TV programs, movies, literature, and so on. Practices refer to the way of life that is held by a particular group of people that can be reflected from their everyday behavior such as customs ("Thanksgiving Festival"), daily life ("America's national sport is baseball' and "an Indian student ... plays street games"), and society (such as "New Zealand ... its recycling programs ... have been very successful" and "Lots of Icelanders live in Reykjavik"). Perspective deals with the world view maintained by the members of a group or society, such as values and beliefs. It is divided into several aspects, namely inspirations ("equality"), myths (horoscopes and superstitions),

Journal on English as a Foreign Language, 10(1), 163-184

Copyright @ 2020 by JEFL, p-ISSN 2088-1657; e-ISSN 2502-6615 
and world views ("... in the UK and the US ... reality shows are just entertainment ... [viewers] do not demand that the programs be 'real'"). At last, Persons are well-known real persons such as Stephan Hawking or Aung San Suu Kyi.

Table 2. Data extract from Bahasa Inggris

\begin{tabular}{|c|c|c|c|c|}
\hline Theme & Page & Section & $\begin{array}{l}\text { Cultural aspect } \\
\text { (Regions: } \\
\text { Number of } \\
\text { items) }\end{array}$ & $\begin{array}{c}\text { Abstract } \\
\text { (Region: Cultural aspect) }\end{array}$ \\
\hline \multirow{4}{*}{$\begin{array}{l}\text { Chapter 5: } \\
\text { Who was } \\
\text { involved? } \\
\text { (News } \\
\text { item) }\end{array}$} & 64 & $\begin{array}{l}\text { Reading: } \\
\text { News }\end{array}$ & $\begin{array}{l}\text { Product } \\
\text { (Eng-speaking } \\
\text { country: 1) }\end{array}$ & $\begin{array}{l}\text { Since 1981, the Humber Bridge } \\
\text { (Eng-speaking country: product) ... }\end{array}$ \\
\hline & & & $\begin{array}{c}\text { Practice } \\
\text { (Indonesia: 1) }\end{array}$ & $\begin{array}{l}\ldots . \text { trend of living in Jakarta... Living } \\
\text { in an apartment has increasingly } \\
\text { become popular (Indonesia: } \\
\text { practice) }\end{array}$ \\
\hline & 73 & $\begin{array}{l}\text { Reading: } \\
\text { News }\end{array}$ & $\begin{array}{l}\text { Person } \\
\text { (Eng-speaking } \\
\text { country: } 1)\end{array}$ & $\begin{array}{l}\text {...Trisha Prabhu (Eng-speaking } \\
\text { country: person), from Illinois, who } \\
\text { as only } 13 \text { when she devised the } \\
\text { technology. }\end{array}$ \\
\hline & 77 & $\begin{array}{l}\text { Cloze } \\
\text { news } \\
\text { exercise }\end{array}$ & $\begin{array}{c}\text { Product } \\
\text { (Eng-speaking } \\
\text { country: } 3 \text { ) } \\
\text { (Non-English } \\
\text { country: 1) } \\
\text { Person } \\
\text { (Eng-speaking } \\
\text { country: 1) } \\
\text { (Non-English } \\
\text { country: } 1 \text { ) }\end{array}$ & $\begin{array}{l}\text { British playwright Harold Pinter } \\
\text { (Eng-speaking country: person), ... } \\
\text {... of the Nobel literature (Eng- } \\
\text { speaking country: product) } \\
\ldots \text { best-known dramatic for plays ... } \\
\text { The Birthday Party and The Caretaker } \\
\text { (Eng-speaking country: product) ... } \\
\text {... by Swedish Academy (Non-Eng- } \\
\text { speaking country: product) head } \\
\text { Horace Engdahl (Non-Eng speaking } \\
\text { country: person) ... } \\
\text {... Reuter Television (Eng-speaking } \\
\text { country: product) ... }\end{array}$ \\
\hline
\end{tabular}

(Source: Widiati et al, 2018)

It is important to note that since Yuen's (2011) investigation focused only on the representation of the foreign culture that is categorized into target culture (British and American) and International culture (except Hong Kong), it was added another area that is necessary to be included which is source culture or learners' own culture. Subsequently, the investigation in the present study includes all materials comprising texts and images explicitly related to the

Journal on English as a Foreign Language, 10(1), 163-184

Copyright (C) 2020 by JEFL, p-ISSN 2088-1657; e-ISSN 2502-6615 
target, source, and international culture. For example, a cultural product of English speaking countries is counted in a reading section in the textbook Bahasa Inggris since it tells a specific place ("Since 1981, the Humber Bridge ...") (see Table 2 for more detail information). The same item from any of the cultural aspects is counted more than once if it appears again in a different section.

\section{Intercultural interaction}

Concerning examining intercultural interaction in the textbook, it employed a framework proposed by Song (2013). Song (2013) analyzed Korean textbooks that are developed according to the national curriculum. The researcher categorizes intercultural interactions into three aspects (superficial interaction, hybridization, and critical reflection). Superficial interaction means the depiction of physical cultural products such as food and travel. It indicates that different cultures have their own exclusivity that should be respected, such as all cultures have their cooking and eating and they should be considered as cultural heritage. Hybridization involves a combination of more than two different cultural norms, values, traditions, and customs. For example, the depiction combining Korean traditional music, Samulnori, and a Korean man break-dancing, accompanying text says, "Deeply rooted in rich tradition, the ancient and the modern, the East and the West all join together in amazing harmony here." Critical reflection refers to the involvement in further discussion or reflection of beliefs, history, values, or conflicts related to certain cultures. Song noted the example of Martin Luther King Jr and Marian who demonstrate discrimination and unequal power experienced by African-Americans in the USA.

Unlike the analysis of cultural representation that investigates all materials or sections, the analysis of intercultural interaction focuses only on reading sections and pictures with its following tasks since they include the most contextualized and intercultural interaction representations. For example, a set of pictures accompanied by questions in Contextual English (see Figure 1) is categorized as critical reflection. It addressed the comparison between a tense situation during the war and peaceful conditions in a rice field. The questions following it were considered fruitful to lead students to engage in an intercultural relationship.

Journal on English as a Foreign Language, 10(1), 163-184

Copyright @ 2020 by JEFL, p-ISSN 2088-1657; e-ISSN 2502-6615 


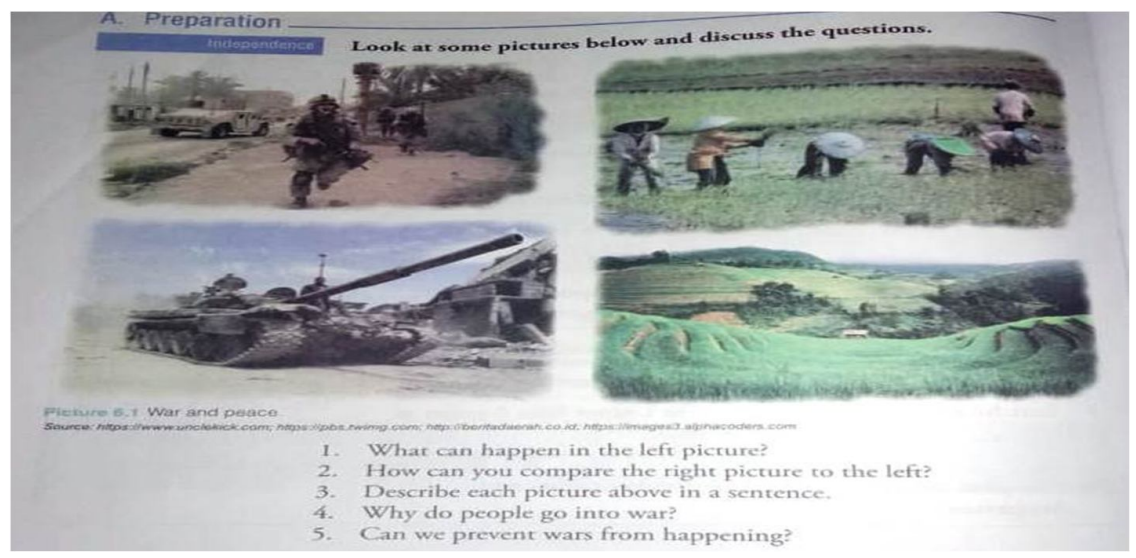

Figure 1. Data sample from Contextual English

\section{FINDINGS}

\section{Cultural Representation}

The textbooks were first analyzed with respect to cultural representation which consists of cultural regions and cultural aspects. The cultural representations were identified through all texts and images in the textbooks. They were identified by their region origins (Indonesia, non-English-speaking countries, Asia, Africa, or English-speaking countries) and cultural aspects (products, practices, perspectives, and persons).

Table 3. The cultural representation in Bahasa Inggris

\begin{tabular}{|c|c|c|c|c|c|}
\hline \multirow{3}{*}{ Aspects } & \multicolumn{5}{|c|}{ Regions } \\
\hline & \multirow[b]{2}{*}{ Indonesia } & \multicolumn{3}{|c|}{ International } & \multirow{2}{*}{$\begin{array}{l}\text { English- } \\
\text { speaking } \\
\text { countries }\end{array}$} \\
\hline & & $\begin{array}{c}\text { Non-English- } \\
\text { speaking countries }\end{array}$ & Asia & Africa & \\
\hline Products & 43 & 4 & 5 & 1 & 41 \\
\hline Practices & 6 & - & - & - & 7 \\
\hline Perspectives & - & - & - & - & - \\
\hline Person & 15 & 2 & 1 & - & 11 \\
\hline Total & 66 & 7 & 6 & 1 & 61 \\
\hline$\%$ & 46.81 & 4.96 & 4.26 & 0.71 & 43.26 \\
\hline
\end{tabular}

Table 3 shows that the cultural representation of Indonesian and Englishspeaking countries cultures was predominant in the textbook Bahasa Inggris. It was approximately 90 percent of cultural contents in the government textbook that were depicted of Indonesian (46.81\%) and English-speaking countries (43.26\%). In terms of cultural aspects, the textbooks mainly presented it through the product. Indonesian cultures related to products frequently appeared in 
terms of places such as Jakarta, Surabaya, and Denpasar. The appearance of Institutions such as Indonesian schools, the institution of the government, and media was also considered frequent. Cultural products of English-speaking countries were also often presented in terms of places such as Seattle, Brainbridge Island, Pike Place Market, and Humber Bridge. While cultural products of Indonesian and English-speaking countries were redundant, those of Non-English-speaking countries, Asia, and Africa were underrepresented. Furthermore, the textbook did not include the cultural aspects of the three regions in terms of cultural practice. Meanwhile, cultural practices of Indonesian (e.g. ...trend of living in Jakarta... Living in an apartment has increasingly become popular) and English-speaking countries (e.g. ...Pike Place Market... The area is a festival of sounds, tastes ...It is called as the 'soul of Seattle) appeared six and seven times respectively. Regarding cultural perspective, unfortunately, after careful examination, such an aspect cannot be found in the textbook. Like any other cultural aspects, cultural persons were also dominated by Indonesian and English-speaking countries. The textbook had more real people from Indonesia (e.g. Tri Rismaharini, Basuki Tjahaja Purnama) and Britain or America (e.g. Harold Pinter, Trisha Prabhu) than those from nonEnglish countries, Asia, and Africa.

Table 4. The representation of culture in Pathway to English

\begin{tabular}{lccccc}
\hline & \multicolumn{5}{c}{ Regions } \\
\cline { 2 - 5 } Aspects & Indonesia & $\begin{array}{c}\text { International } \\
\text { Non-English- } \\
\text { speaking western } \\
\text { countries }\end{array}$ & Asia & Africa & $\begin{array}{c}\text { English- } \\
\text { speaking } \\
\text { countries }\end{array}$ \\
\hline Products & 65 & 23 & 43 & 4 & 62 \\
Practices & 7 & 3 & 3 & 2 & 1 \\
Perspectives & 2 & 1 & - & - & - \\
Person & 18 & 9 & 6 & 2 & 21 \\
Total & 92 & 36 & 52 & 7 & 84 \\
$\%$ & 33.95 & 13.28 & 19.19 & 2.58 & 31.00 \\
\hline
\end{tabular}

In regard to Table 4, it can be seen that the Indonesian cultures (33.95\%) took the highest portion of cultural content in the textbook Pathway to English. It is followed by the cultures of English-speaking countries (31.00\%). Cultures of Asia (19.19\%), Non-English countries (13.28\%), and Africa (2.58\%) then come respectively. It is obvious that cultural products appeared most frequently. Similar to the previous textbook, cultural products were represented the most by mentioning cities and countries (e.g. Jakarta, Palembang, New York Colorado, France, and The United States,) and institutions (e.g. ASEAN, UN, and Indira 
Gandhi Institute of Child Medicine). Cultural practices were frequently depicted in the form of custom (Duanwu Festival, Ubud Festival, and the anniversary of Victory Day). Cultural practices of African countries only talked about conflict and poverty. For example, conflict in Somalia forced their people to leave their homeland and live in a refugee settlement. The representation of cultural perspectives, for example, 'Paperboys took a very important role in countries such as Holland, the US, ...' were barely included in the textbook. Furthermore, the cultural perspectives from English-speaking countries, Asia, and Africa did not exist in the entire book. The real persons from English speaking countries (Prince William, Kate Middleton, and Barack Obama) appeared more than those from Indonesia or other Asian countries, non-English countries, as well as Africa.

Table 5. The representation of culture in Contextual English

\begin{tabular}{lccccc}
\hline & \multicolumn{5}{c}{ Regions } \\
\cline { 2 - 5 } \multicolumn{1}{c}{ Aspects } & Indonesia & $\begin{array}{c}\text { International } \\
\text { Non-English- } \\
\text { speaking western } \\
\text { countries }\end{array}$ & Asia & Africa & $\begin{array}{c}\text { English- } \\
\text { speaking } \\
\text { countries }\end{array}$ \\
\hline Products & 24 & 23 & 17 & 1 & 53 \\
Practices & 1 & - & - & - & - \\
Perspectives & - & 2 & 2 & - & - \\
Person & 4 & 11 & 1 & - & 27 \\
Total & 29 & 35 & 20 & 1 & 81 \\
$\%$ & 17.47 & 21.08 & 12.05 & 0.60 & 48.80 \\
\hline
\end{tabular}

Compared to the two other textbooks, Contextual English has the least cultural representation (see Table 5). The textbook seems to avoid depicting particular cultural origins. The findings showed that the cultural contents in Contextual English were dominated by those of English-speaking countries $(48.80 \%)$. It is followed by cultures of non-English speaking countries (21.08\%). The representations of Indonesian, Asia, and African cultures only covered $17.47 \%, 12.05 \%$, and $0.60 \%$ respectively. Almost half of the representation of cultural products was from English-speaking countries. It was mostly in terms of songs (Where Do the Children Play, Apologize, Live Like We're Dying), and superhero characters such as Spiderman, X Man, and Superman can be found in the textbook. The only one cultural practice identified in the textbook was from Indonesia which was Bekasi in West Java is set to implement a ban single-use plastic bag. The cultural perspective appeared only three times. For example, 'In north Europe ... more people consistently report that they have more life satisfaction than people in Middle Europe whose countries are supposed to be 
wealthier.' Besides, the real persons were often reflected through musicians (e.g. Cat Stevens, Timbaland, and Kris Allen) and also poets (Edwin Arlington Robinson, and James Stephen).

In a nutshell, the analysis clearly showed that there was imbalance dissemination of cultural content in all investigated textbooks. The textbooks tended to favor certain cultures over others. Textbook Bahasa Inggris and Pathway to English showed the domination of Indonesian culture (the learner's own culture) and the cultures of the English-speaking countries. At the same time, the dominancy of English-speaking countries' culture can also be seen in textbook Contextual English. Other cultures, namely Asian, non-Englishspeaking western countries and Africans were underrepresented in all of the three textbooks.

\section{Intercultural Interaction}

The second objective of the present study deals with the manifestation of intercultural interactions in the textbooks. Intercultural interaction was identified into three categories, i.e. superficial interaction, hybridization, and critical reflection.

Table 6. Intercultural interaction in Bahasa Inggris

\begin{tabular}{lcc}
\hline \multicolumn{1}{c}{$\begin{array}{c}\text { Intercultural } \\
\text { interaction }\end{array}$} & Chapter (Theme) & Nations or ethnicity \\
\hline $\begin{array}{l}\text { Superficial } \\
\text { interaction }\end{array}$ & 5 (International organization) & $\begin{array}{c}\text { Sweden and England } \\
\text { Asian and Pacific Countries } \\
\text { Vietnam, Indonesia, Laos }\end{array}$ \\
$\begin{array}{l}\text { Hybridization } \\
\begin{array}{l}\text { Critical } \\
\text { reflection }\end{array}\end{array}$ & $\begin{array}{c}\text { (Cooperation) } \\
-\end{array}$ & (Training farmers due to \\
conflict) & The USA and Republic of Congo \\
\hline
\end{tabular}

Table 6 demonstrates the dissemination of intercultural interactions in the textbook Bahasa Inggris. The textbook included three superficial interactions, one critical reflection, and no hybridization. Superficial interaction can be found in a short text telling cooperation between countries. The text said, for example, 'International donors to Vietnam, Indonesia, and Laos announced on Thursday.' Other superficial interactions can be seen in terms of literature, and international organization. Related to critical reflection, English-speaking countries were seen as more superior than African ones. For instance, a text that discussed The USA creating training facilities for 2000 Congolese cocoa farmers who cannot work in their country due to conflict.

Journal on English as a Foreign Language, 10(1), 163-184

Copyright (C) 2020 by JEFL, p-ISSN 2088-1657; e-ISSN 2502-6615 
Table 7. Intercultural interaction in Pathway to English

\begin{tabular}{|c|c|c|}
\hline $\begin{array}{l}\text { Intercultural } \\
\text { interaction }\end{array}$ & Chapter (Theme) & Referred nations or ethnicity \\
\hline Superficial & 3 (Persons) & Estonia, Moldova, \\
\hline \multirow[t]{4}{*}{ interaction } & 3 (Commemoration) & Singapore and Indonesia \\
\hline & 4 (Currency) & Indonesia and The USA \\
\hline & 4 (Person) & England, Indonesia, the \\
\hline & 4 (Cooperation) & $\begin{array}{c}\text { Philippines } \\
\text { Cambodia, Thailand, Indonesia, } \\
\text { Cambodia, Japan }\end{array}$ \\
\hline Hybridization & - & - \\
\hline Critical & 3 (Poverty and conflict) & Somalia, Spain, The USA, Kenya \\
\hline reflection & $\begin{array}{c}4 \text { (History of newspaper } \\
\text { delivery) }\end{array}$ & $\begin{array}{c}\text { Holland, The USA, Australia, } \\
\text { England, Ireland, France, New } \\
\text { Zealand, and Canada }\end{array}$ \\
\hline
\end{tabular}

The second textbook Pathway to English covered seven intercultural interactions (see Table 7) were five of them fell under the terms of superficial interactions. One of the superficial interactions was about a commemoration that involved two countries. For example, students of Singapore International School in Semarang commemorated Earth Day by planting trees. Superficial interactions can also be found in terms of person, currency, and cooperation. Meanwhile, the aspect of critical reflection was illustrated by the history of newspaper delivery in Western countries where the delivery was first done by paperboys. The paperboys were seen as an important role in western countries since this is the first paying-job available for children and young teenagers, especially males. Another critical reflection was in the form of poverty and conflict in expanding countries, particularly in Africa. It can be seen in a text discussing Somalian refugees in a UN shelter who were forced to leave their land due to civil war and drought.

The manifestation of intercultural interaction in textbook Contextual English is shown in Table 8. The textbook covered two superficial interactions related to arts and international organizations. For instance, unit 5 is introduced by several pictures of real musicians from English-speaking countries and Indonesia. Related to critical reflection, several contents were taken into consideration such as peace, conflict, prosperity and so on. For example, the comparison of two pictures where one shows armies and armored cavalry in the middle of a battle, and the other shows farmers in a peaceful paddy field. The pictures were accompanied by several questions that may lead students to

Journal on English as a Foreign Language, 10(1), 163-184

Copyright @ 2020 by JEFL, p-ISSN 2088-1657; e-ISSN 2502-6615 
have cultural awareness such as 'what happened in the pictures? Why do people go into war? Can we prevent wars from happening?

Table 8. Intercultural interaction in Contextual English

\begin{tabular}{|c|c|c|}
\hline $\begin{array}{c}\text { Intercultural } \\
\text { interaction }\end{array}$ & Chapter (Theme) & Referred nations or ethnicity \\
\hline Superficial & 5 (Arts) & Indonesia, The USA, and England \\
\hline interaction & 5 (International organization) & ASEAN countries \\
\hline Hybridization & - & . \\
\hline Critical & 2 (Shared desire for peace) & England and Germany \\
\hline \multirow[t]{3}{*}{ reflection } & 5 (Peace and conflict) & $\begin{array}{l}\text { White western people and colored } \\
\text { Asians }\end{array}$ \\
\hline & 7 (Industrial revolution) & $\begin{array}{c}\text { European countries, The USA, } \\
\text { Japan, China, and Korea }\end{array}$ \\
\hline & 8 (Prosperity and happiness) & $\begin{array}{c}\text { Northern Europe, Middle Europe, } \\
\text { and South-east Asia }\end{array}$ \\
\hline
\end{tabular}

In short, the intercultural interactions had not been properly represented in the textbooks under investigation. The majority of intercultural interactions are represented as superficial interactions, rather than fruitful intercultural comprehension, comparison, and knowledge. Superficial interactions often occurred when Indonesian products (mostly governmental institutions) were mixed with those from other Asian countries. Further analysis shows that there was no single hybridization found in all textbooks. Related to critical reflections, the textbooks largely demonstrated British and American in positive values and significant positions. On the other side, African people are often portrayed through wars and violence.

\section{DISCUSSION}

There are two issues the present study attempts to raise which are the representations of culture and intercultural interaction in three widely-used English textbooks in Indonesia. Firstly, regarding the cultural content, the findings indicate that cultures of Indonesia (learner's own culture), and cultures of English-speaking countries predominantly cover the cultural content in textbooks Bahasa Inggris and Pathway to English. Meanwhile, cultures of Englishspeaking countries are predominant in textbook Contextual English where almost half of its cultural content fell under the terms of cultures of Englishspeaking countries. Source culture or learners' cultural dominance in English textbooks is also revealed elsewhere (Hermawan \& Lia, 2012; Kim \& Paek, 2015; Parlindungan et al., 2018). Related to the domination of the culture of Englishspeaking countries over others, the similar findings have also been discovered 
by previous textbook studies (Chao, 2011; Rashidi et al., 2016; Shin et al., 2011; Song, 2013; Yuen, 2011).

The present study reveals the numbers of cultures of non-Englishspeaking countries and other Asian countries are much lesser than that of cultures of the two previous regions. At the same time, the cultures of Africa countries seem to be left behind as they have the least amount of coverage. Furthermore, African countries are mostly presented with poverty and conflict as English-speaking countries (Britain and The USA) are depicted with superiority and more positive roles. These findings are partially in line with textbooks studies not only in the Indonesian context (Setyono \& Widodo, 2019), but also other contexts such as Korea (Sherman, 2010; Song, 2013), Hong Kong (Yuen, 2011), and Brazil (Taylor-Mendes, 2009). Since English is seen as an international language, the cultural content in textbooks should not only focus on cultures from particular regions. Cultures from other regions such as Asia, Africa, and non-English speaking countries should be taken into consideration in selecting materials in English textbooks. By considering so, hopefully, it can be in line with the current Indonesian curriculum which aimed to lead learners to have the knowledge and awareness of cultural diversity in the level of both national and international.

Concerning the cultural aspects, the examined textbooks are lacking deep cultural materials since the content of cultural products take the highest portion with place and institution being the major type. On the other hand, the other three aspects less frequently appear especially practice and perspectives. These findings are akin to textbooks investigations by Kang-Young (2009) and Yuen (2011). Yuen (2011) reports that English textbooks in Hong Kong frequently cover superficial cultural contents as a cultural product such as entertainment travel, and food took the highest portion. In a similar vein, KangYoung (2009) finds that Korean textbooks have a strong tendency to include Big $C$ (products) of target-culture learning such as a set of memorable facts and statistics in arts, history, and customs. Big C and small c (practices) together should be taken into account to extend the effectiveness and appropriateness of intercultural communication. However, knowledge of small c is believed more crucial to impede misunderstandings in intercultural communication than the Big C (Kang-Young, 2009; Sadeghi \& Sepahi, 2018; Wintergerst \& McVeigh, 2011). Therefore, learners' preferences for cultural practice might indicate their desire to be successful in intercultural communications.

Journal on English as a Foreign Language, 10(1), 163-184

Copyright @ 2020 by JEFL, p-ISSN 2088-1657; e-ISSN 2502-6615 
Intercultural interaction has not been appropriately represented in the investigated textbooks. Intercultural interactions are fragmented, limited, and superficial. Instead of concerning fruitful intercultural understanding, comparison and awareness, most intercultural interactions in the textbook are depicted into superficial interaction. Cultural products (mostly governmental institutions) from Indonesia being mixed with those from other Asian countries are largely demonstrated in the textbooks. These findings are partially consistent with previous textbooks studies (Chao, 2011; Kim \& Paek, 2015; Roohani \& Molana, 2013). Chao (2011) contends that intercultural issues are an instrumental part of the representation of cultural content in textbooks. If intercultural interactions were only represented with low-level exposure to superficial culture, learners would be less reflective critical thinkers (Roohani \& Molana, 2013).

Another aspect of intercultural interactions that can be found in the textbook is the critical reflection. Most of the critical reflections in the textbook are represented through the depiction of English-speaking countries (mostly Britain and The USA). British and American are often depicted with positive values and important roles. On the other hand, African people are frequently represented through conflicts and poverty (Sherman, 2010; Song, 2013; TaylorMendes, 2009; Yuen, 2011). These findings discover the representations of intercultural interactions in the textbooks are still not depicted in fair and unbiased ways. Besides, all of the critical reflections in the examined textbooks do not include any Indonesian cultures. The textbooks do not appropriately allow learners to explore their cultural identity. Not a single intercultural interaction leads learners to look at Indonesian culture from a different perspective. However, awareness of how they see themselves as others might see them is crucial to help learners establish intercultural communication effectively and appropriately (Sobkowiak, 2016).

The domination of cultural contents from Indonesia as well as Englishspeaking countries should be readdressed by authors and publishers. Besides, intercultural interactions in the investigated textbooks need to be refurbished in a way that supports learners to enhance their intercultural awareness. In cooperating cultural materials in a textbook, a textbook is supposed to not only embrace simple cultural facts, but also norms, beliefs, or values held by a particular group of people, and to include a variety of 'Englishes' in teaching materials (Shin et al., 2011). Moreover, since the textbooks do not appropriately approach cultural content, especially international cultures, English teachers must find a way to address the scarcity in their classrooms. Teachers may

Journal on English as a Foreign Language, 10(1), 163-184

Copyright @ 2020 by JEFL, p-ISSN 2088-1657; e-ISSN 2502-6615 
utilize various cultural activities focused on international cultures through texts, pictures, tape recordings, videos, and internet and so on to develop their students' cultural knowledge. Besides, teachers need to address the shortcoming of intercultural interactions that were mostly illustrated at a superficial level and centered on English-speaking countries. Teachers may supply it with discussion in a way that encourages students to investigate cultural contents beyond cultural facts. For instance, teachers can elaborate on the picture of nation leaders gathering in the ASEAN forum. This picture has a positive image of countries' cooperation in South East Asia. However, it can be elaborated by discussing the reason why South East Asia people established ASEAN. Teachers may also invite students to look at historical as well as current tensions between ASEAN countries and how Indonesia positions themselves in those tensions.

\section{CONCLUSION}

Given the status of English as a lingua franca, English language education has a responsibility to promote learners' ability to communicate effectively and appropriately in various cultural settings. It happens since English is no longer seen as a language of English-speaking countries as English communication takes place between people from multicultural backgrounds. The findings of the present study showed the imbalance portion of cultural content in the three English textbooks used in Indonesia where cultures from Indonesia and English-speaking countries have their dominancy. Despite the redundant content of Indonesian culture, there were no any of them involved in deep intercultural interactions. Intercultural interactions were demonstrated in fragmented, limited, and superficial ways. Therefore, textbooks authors, as well as publishers, need to give proper exposure to international cultures and deep intercultural interactions to ensure learners experience intercultural rich materials. Besides, if such textbooks were used in English classrooms, teachers should be creative in adding supplementary materials or activities to patch up the shortcomings of the textbooks.

\section{REFERENCES}

Baker, W. (2012a). From cultural awareness to intercultural awareness: Culture in ELT. ELT Journal, 66(1), 62-70. https://doi.org/10.1093/elt/ccr017

Baker, W. (2012b). Global cultures and identities: Refocusing the aims of ELT in Asia through intercultural awareness. In T. Muller, S. Herder, J. Adamson, \& P. S. Brown (Eds.), Innovating EFL Teaching in Asia (pp. 2334). Palgrave Macmillan UK. https://doi.org/10.1057/9780230347823_3

Journal on English as a Foreign Language, 10(1), 163-184

Copyright (C) 2020 by JEFL, p-ISSN 2088-1657; e-ISSN 2502-6615 
Bennett, J. M., Bennett, M. J., \& Allen, W. (2003). Developing intercultural competence in the language classroom. In D. L. Lange \& R. M. Paige (Eds.), Culture as the core: Perspectives on culture in second language learning (pp. 237-270). Information Age Pub.

Byram, M. (1997). Teaching and assessing intercultural communicative competence. Clevedon. Multilingual Matters.

Chao, T. (2011). The hidden curriculum of cultural content in internationally published ELT textbooks: A closer look at new American inside out. The Journal of Asia TEFL, 8(2), 189-210.

Chapelle, C. A. (2009). A hidden curriculum in language textbooks: Are beginning learners of French at U.S. universities taught about Canada? The Modern Language Journal, 93(2), 139-152. https://doi.org/10.1111/1540-4781.2009.00852.x

Chlopek, Z. (2008). The intercultural approach to EFL teaching and learning. English Teaching Forum, 4, 10-27. Retrieved from https://americanenglish.state.gov /files/ae/resource_files/08-46-4-c.pdf

Hermawan, B., \& Lia, N. (2012). Traces of cultures in English textbooks for primary education. Indonesian Journal of Applied Linguistics, 1(2), 49-61. https://doi.org/10.17509/ijal.v1i2.84

Hymes, D. (1972). On communicative competence. In J. B. Pride \& J. Holmes (Eds.), Sociolinguistics. Harmondsworth: Penguin.

Ishikawa, T. (2016). World Englishes and English as a lingua franca: Conceptualising the legitimacy of Asian people's English. Asian Englishes, 18(2), 129-140. https://doi.org/10.1080/13488678.2016.1171672

Jenkins, J. (2012). English as a lingua franca from the classroom to the classroom. ELT Journal, 66(4), 486-494. https://doi.org/10.1093/elt/ccs040

Kachru, B. (1985). Standards, codification and sociolinguistic realism: The English language in the outer circle. In R. Quirk \& H. G. Widdowson (Eds.), English in the World (pp. 11-32). Cambridge: Cambridge University Press.

Kang-Young, L. (2009). Treating culture: What 11 high school EFL conversation textbooks in South Korea do. English Teaching: Practice and Critique, 8(1), 76-96.

Kim, S., \& Paek, J. (2015). An analysis of culture-related content in English textbooks. Linguistic Research, 32, 83-104. https: //doi.org/10.17250/khisli.32..201507.005

Kusumaningputri, R., \& Widodo, H. P. (2018). Promoting Indonesian university students' critical intercultural awareness in tertiary EAL classrooms: The

Journal on English as a Foreign Language, 10(1), 163-184

Copyright @ 2020 by JEFL, p-ISSN 2088-1657; e-ISSN 2502-6615 
use of digital photograph-mediated intercultural tasks. System, 72, 49-61. https://doi.org/10.1016/.system.2017.10.003

Liddicoat, A., \& Scarino, A. (2013). Intercultural language teaching and learning. Hoboken: Wiley-Blackwell.

Munandar, M. I., \& Ulwiyah, I. (2012). Intercultural approaches to the cultural content of Indonesia's high school ELT textbooks. Cross-Cultural $\begin{array}{lll}\text { Communication, } & \text { 6(5), }\end{array}$ http://dx.doi.org/10.3968/j.ccc.1923670020120805.975

Ndura, E. (2004). ESL and cultural bias: An analysis of elementary through high school textbooks in the Western United States of America. Language, Culture and Curriculum, 17(2), 143-153. https://doi.org/10.1080/07908310408666689

Otlowski, M. (2003). Ethnic diversity and gender bias in EFL textbooks. Asian EFL Journal, 5(2), 1-15. Retrieved from https:/www.asian-efljournal.com/june_03_mo.pdf

Parlindungan, F., Rifai, I., \& Safriani, A. (2018). The representation of Indonesian cultural diversity in middle school English textbooks. Indonesian Journal of Applied Linguistics, 8(2), 289-302. https://doi.org/10.17509/ijal.v8i2.13276

Rashidi, N., Meihami, H., \& Gritter, K. (2016). Hidden curriculum: An analysis of cultural content of the ELT textbooks in inner, outer, and expanding circle countries. Cogent Education, 3(1), 117. https://doi.org/10.1080/2331186X.2016.1212455

Richards, J. C. (2001). The role of textbooks in a language program. RELC Guidelines, 23(2), 12-16.

Roohani, A., \& Molana, E. (2013). An investigation into cultural representation in interchange textbooks. Issues in Language Teaching (ILT), 2(2), 113-136.

Sadeghi, K., \& Sepahi, Z. (2018). Cultural content of three EFL textbooks: Teachers' and learners' cultural preferences and cultural themes of textbooks. Pedagogies: An International Journal, 13(3), 222-245. https://doi.org/10.1080/1554480X.2017.1417128

Setyono, B., \& Widodo, H. P. (2019). The representation of multicultural values in the Indonesian Ministry of Education and Culture-Endorsed EFL textbook: A critical discourse analysis. Intercultural Education, 30(4), 383397. https://doi.org/10.1080/14675986.2019.1548102

Sherman, J. E. (2010). Uncovering cultural bias in EFL textbooks. Issues in Applied Linguistics, 18(1), 27-53. Retrieved from https://escholarship.org/uc/item/4rc558zw 
Shin, J., Eslami, Z. R., \& Chen, W.-C. (2011). Presentation of local and international culture in current international English-language teaching textbooks. Language, Culture and Curriculum, 24(3), 253-268. https://doi.org/10.1080/07908318.2011.614694

Sobkowiak, P. (2016). Critical thinking in the intercultural context: Investigating EFL textbooks. Studies in Second Language Learning and Teaching, 6(4), 697-716. https://doi.org/10.14746/ssllt.2016.6.4.7

Song, H. (2013). Deconstruction of cultural dominance in Korean EFL textbooks. Intercultural Education, 24(4), 382-390. https://doi.org/10.1080/14675986.2013.809248

Sudarwati, Th. M., \& Grace, E. (2018). Pathway to English: For SMA/MA Grade XII. Jakarta: Erlangga.

Sugeng, B., Saputri, F. R., \& Anindyka Sekar Trisnasih. (2019). Contextual English: For Grade XII of Senior High Schools. Surakarta: PT Tiga Serangkai Pustaka Mandiri.

Tajeddin, Z., \& Teimournezhad, S. (2015). Exploring the hidden agenda in the representation of culture in international and localised ELT textbooks. The Language Learning Journal, 43(2), 180-193. https://doi.org/10.1080/09571736.2013.869942

Taylor-Mendes, C. (2009). Construction of racial stereotypes in English as a foreign language (EFL) textbooks: Images as discourse. In R. Kubota \& A. Lin (Eds.), Race, Culture, and Identities in Second Language Education (pp. 64-80). Routledge.

Weninger, C., \& Kiss, T. (2013). Culture in English as a foreign language (EFL) textbooks: A semiotic approach. TESOL Quarterly, 47(4), 694-716. https://doi.org/10.1002/tesq.87

Widiati, U., Rohmah, Z., \& Furaida. (2018). Bahasa Inggris: Kelas XII SMA/MA/SMK/MAK [English: Grade XII SMA/MA/SMK/MAK]. Jakarta: Pusat Kurikulum dan Perbukuan Kemendikbud.

Widodo, H. P. (2016). Language policy in practice: Reframing the English language curriculum in the Indonesian secondary education sector. In R. Kirkpatrick (Ed.), English Language Education Policy in Asia (Vol. 11, pp. 127-151). Springer International Publishing. https://doi.org/10.1007 9783-319-22464-0_6

Wintergerst, A. C., \& McVeigh, J. (2011). Tips for teaching culture: Practical approaches to intercultural communication. White Plain: Pearson Education.

Yuen, K.-M. (2011). The representation of foreign cultures in English textbooks. ELT Journal, 65(4), 458-466. https: //doi.org/10.1093/elt/ccq089 


\section{Authors' Brief CV}

Tomy Kartika Putra received a bachelor's degree in English Education from Universitas Sebelas Maret Surakarta in 2017. Now, he is currently doing his Master in English Education at the same university. His research interests include thinking skills and intercultural competence in language classrooms.

Dewi Rochsantiningsih is a lecturer at the English Education Department of Universitas Sebelas Maret Surakarta. She earned her Ph.D. in Teacher Education from School of Linguistics and Psychology University of Macquarie, Australia in 2005. Her research interests include TEFL, Classroom Action Research, Teachers' Professional Development, and English Language Teaching Management.

Slamet Supriyadi teaches at the Fine Arts Education Department, the Teacher Training and Education Faculty, Universitas Sebelas Maret Surakarta. He received a doctorate degree in Linguistics Pragmatics from Universitas Sebelas Maret Surakarta in 2008. 